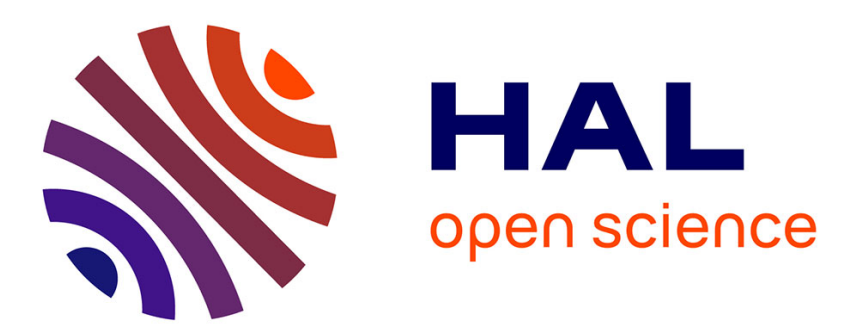

\title{
Evidence of a Blood Pressure Reduction During the COVID-19 Pandemic and Associated Lockdown Period: Insights from e-Health Data
}

Nicolas Girerd, Christophe Meune, Kevin Duarte, Vincent Vercamer, Marilucy Lopez-Sublet, Jean-Jacques Mourad

\section{To cite this version:}

Nicolas Girerd, Christophe Meune, Kevin Duarte, Vincent Vercamer, Marilucy Lopez-Sublet, et al.. Evidence of a Blood Pressure Reduction During the COVID-19 Pandemic and Associated Lockdown Period: Insights from e-Health Data. Telemedicine and e-Health, 2021, 10.1089/tmj.2021.0006 . hal03258094

\section{HAL Id: hal-03258094 \\ https://hal.univ-lorraine.fr/hal-03258094}

Submitted on 11 Jun 2021

HAL is a multi-disciplinary open access archive for the deposit and dissemination of scientific research documents, whether they are published or not. The documents may come from teaching and research institutions in France or abroad, or from public or private research centers.
L'archive ouverte pluridisciplinaire HAL, est destinée au dépôt et à la diffusion de documents scientifiques de niveau recherche, publiés ou non, émanant des établissements d'enseignement et de recherche français ou étrangers, des laboratoires publics ou privés. 


\section{Evidence of a Blood Pressure Reduction during the COVID-19 Pandemic and Associated Lockdown Period}

Nicolas Girerd, $\mathrm{MD} \mathrm{PhD}{ }^{1}$; Christophe Meune, $\mathrm{MD} \mathrm{PhD}^{2}$; Kevin Duarte, $\mathrm{PhD}^{3}$; Vincent Vercamer $\mathrm{PhD}^{4}$; Marilucy Lopez-Sublet, $\mathrm{MD}^{5}$, Jean-Jacques Mourad, MD PhD ${ }^{6}$

1 - Université de Lorraine, Centre d'Investigations Cliniques Plurithématique 1433, Institut Lorrain du Cœur et des Vaisseaux, Vandoeuvre les Nancy France Groupe choc, INSERM U1116, Faculté de Médecine, 54500 Vandoeuvre les Nancy, France ; F-CRIN INI-CRCT (Cardiovascular and Renal Clinical Trialists), Nancy, France; Cardiology Department, Institut Lorrain du Cœur et des Vaisseaux, CHRU Nancy, France.

2 - Department of Cardiology and Université Paris XIII, INSERM S-942, Avicenne Hospital AP-HP, Bobigny, France.

3 - National Institute of Health and Medical Research, Center for Clinical Multidisciplinary Research, INSERM U1116, University of Lorraine, Regional University Hospital of Nancy, French Clinical Research Infrastructure Network Investigation Network Initiative-

Cardiovascular and Renal Clinical Trialists, Nancy, France.

4 - Withings, Issy-les-Moulineaux, France

5 - Department of Internal Medicine and ESH Excellence Centre, Avicenne Hospital AP-HP, Bobigny, France.

6 - Department of Internal Medicine and ESH Excellence Centre, Groupe Hospitalier Paris Saint-Joseph, Paris, France.

\section{Corresponding author:}

Jean-Jacques Mourad, MD-PhD 
Internal Medicine and ESH Excellence Centre, Groupe Hospitalier Paris Saint-Joseph 185 rue Raymond Losserand 75014 Paris, France

Tel: (+33) 144123540

E-mail: jimourad@hpsj.fr

Running title: Blood pressure and COVID-19 lockdown

Keywords: COVID-19; lockdown; blood pressure; hypertension; cardiovascular diseases 


\section{Abstract}

Background: Despite widespread investigation into the incidence of acute myocardial infarction during the COVID-19 pandemic and associated lockdown, no study has examined the situation's impact on blood pressure (BP) levels.

Methods: Measurements of BP and heart rate (HR) were obtained from persons living in the Paris urban area using connected home BP monitors (accessible to patients and health providers through a secured server). Three time periods of e-Health recordings were compared: during the pandemic prior to the lockdown, during the lockdown and the same time period in 2019 .

Results: A total of 297,089 BP recordings from 2,273 participants (age 56.3 \pm 12.8 years, $81.1 \%$ male) were made. During confinement, systolic BP gradually decreased by $3 \mathrm{mmHg}(-$ 2.4 to -3.9$)$, and diastolic $\mathrm{BP}$, by $1.5 \mathrm{mmHg}(-1.4$ to -2.2$)$ (all $\mathrm{p}<0.001)$; this decrease was greater for participants with higher BP ( $\mathrm{p}<0.0001$ each). No significant variation in HR was noted.

Conclusion: Among a very large cohort, we observed a significant decrease in home BP measured with e-Health devices during the first lockdown period. This study emphasizes the research potential of e-Health during the Covid crisis. 


\section{Introduction}

The COVID-19 pandemic that emerged in China in late 2019 rapidly spread around the world, affecting $>70,000,000$ patients globally ${ }^{1}$. In order to reduce the risk of person-toperson transmission and to combat the disease's wide dissemination, many countries have imposed one or more lockdown periods. Several reports highlighted a $20-30 \%$ decrease in the incidence of acute cardiovascular diseases, mainly non-ST segment elevation acute myocardial infarction (AMI) during - and a possible rebound after - the lockdown period ${ }^{2-4}$. In contrast of this large body of evidence, very little is known about blood pressure (BP) and other chronic cardiovascular diseases and/or risk factors.

The application of big data analysis in medicine has opened up new frontiers, such as the development of predictive models and personalised medicine, and population-level health analyses $^{5}$. Given the promotion of home BP monitoring over the last several years, many people are now equipped with wireless monitors, enabling the generation of very large databases.

To address the issue of BP trends during the pandemic and associated lockdown period, we analysed big data registries from users of connected home blood pressure monitors, and compared BP and heart rate (HR) measurements obtained during the lockdown period with data obtained immediately prior to the lockdown, as well as with data obtained from the same period in 2019.

\section{Methods}

All adults living in the Paris region with an ambulatory 'Withings' BP monitor, having at least one available BP measurement recorded in the three studied time periods - namely, 
during the COVID-19 lockdown period (from 17 March to 11 May 2020), prior to the lockdown and in 2019 - were included in the analysis. Measurements were obtained and automatically transmitted after a complete de-anonymisation process and with participants' consent on a secured server.

In order to assess changes over time in systolic blood pressure (SBP), diastolic blood pressure (DBP) and HR, repeated measures linear mixed effect models were constructed, with time as fixed effect and patient as random effect. Models were also assessed by adjusting for age and gender as fixed effects. The adjusted means were calculated for each period, and the pairwise differences of adjusted means were compared using Tukey's post hoc t-test from the model. According to French law, as we only had access to anonymized data, no formal IRB approval was needed.

\section{Results}

From 1 January 2019 to 5 May 2020, 297,089 BP recordings were available from 2,273 participants. Most participants were $<60$ years old $(58.5 \%$, mean age was $56.3 \pm 12.8$, range 19 to 95$)$, with the majority being male $(81.1 \%)$. The number of BP measurements performed before and after the lockdown were 1.5/week (0.7-3.9) and 1.6/week (0.7-4.3), respectively. SBP and DBP both significantly declined during the lockdown period. SBP gradually decreased during the first 4 weeks of confinement, reaching a 3-mmHg decrease plateau (range $=-2.4$ to $-3.9 \mathrm{mmHg}$ decrease from week 4 to week 7 , all $\mathrm{p}<0.001$; Figure 1 and Table 1). A similar pattern was also observed for DBP, with a gradual decrease up to week 4 of lockdown, and a plateau of decrease of approximately $1.5 \mathrm{mmHg}$ (range -1.35 to $-2.22 \mathrm{mmHg}$ decrease from week 4 to week 7 , all $\mathrm{p}<0.001$; Figure 1). Similar results were observed when taking into account age and sex. In contrast, changes in HR were limited to a less than $1 \mathrm{bpm}$, non-significant decrease (Figure 1). 
The main driver of BP changes during the lockdown was the BP level prior to the lockdown. Participants with higher systolic BP had higher decrease in systolic BP during the lockdown (Beta for each $10 \mathrm{mmHg}$ increase in systolic BP prior to the lockdown $=-1.91 \pm 0.12$, $\mathrm{p}<0.0001$, whereas age and sex had no significant effect ( $\mathrm{p}=0.9$ and 0.054 , respectively). Similarly, participants with higher diastolic BP had higher decreases in diastolic BP during the lockdown (Beta for each $10 \mathrm{mmHg}$ increase in diastolic BP prior to lock down $=$ $-1.43 \pm 0.12, p<0.0001)$, whereas sex had no significant effect $(\mathrm{p}=0.15)$.

\section{Discussion}

Our study shows that participants experienced a 3-mmHg SBP decrease and a $1.5-\mathrm{mmHg}$ decrease DBP decrease (which was not accompanied by an HR reduction) during the lockdown related to the COVID-19 crisis.

Several behavioural changes have been observed during the COVID-19 pandemic and associated lockdown. Most of these were expected to adversely impact BP - e.g. sedentary lifestyles leading to increased food and alcohol intake, and in turn increased weight, and greater psychological tensions ${ }^{6}$. Some patients may have also stopped taking their medicine in the early phase of the pandemic due to preliminary warnings about a possible interaction between angiotensin converting enzyme inhibitors and the COVID-19 outcome ${ }^{7}$. A recent survey presented during the Argentine Congress of Cardiology indicated there were fewer emergency department (ED) admissions during the lockdown period compared to the period just prior to the isolation, but there was a greater proportion of patients having hypertension as defined by a SBP $\geq 160 \mathrm{mmHg}$ and/or a $\mathrm{DBP} \geq 100 \mathrm{mmHg}$

(www.sciencedaily.com/releases/2020/11/201119083923.htm). Although our results appear in contradiction with the survey's findings, there might be selection bias, as the authors only report on patients admitted in the $\mathrm{ED}$, and both their acute disease and transportation to the 
ED during the pandemic may be particularly stressful and thus responsible for increased BP measurements.

In contrast, we studied a very large population, and all measurements were homemade. In addition, the BP reduction we observed occurred less than one month following the onset of the lockdown and was of a higher magnitude when compared to the minimal BP changes observed during the beginning of the pandemic, suggesting a direct link between the lockdown and BP reduction. The exact link cannot be derived from our study. Nonetheless, it is very unlikely that many therapeutic changes were performed during that period. In addition, we report a greater $\mathrm{BP}$ reduction among people having the most elevated $\mathrm{BP}$ prior to this time. We therefore hypothesise a decreased occupational stress level and increased treatment compliance during the lockdown, thereby resulting in greater BP control ${ }^{8}$.

France was one of the countries most affected by COVID-19 in Europe. The French government decreed a period of confinement from 17 March to 11 May 2020. During this period, a decrease in hospitalizations for AMI was reported ${ }^{3}$. The present study particularly focused on participants living in the Paris urban region, which was massively impacted by the COVID-19 epidemic and in which the lockdown was strictly enforced, resulting in a sudden and prolonged cessation of non-essential activities. Whether our results of decreased BP may account for part of the observed trends in AMI during the lockdown remains to be established.

\section{Limitations}

Some limitations deserve consideration. First, our analysis is limited by our inability to collect clinical data about medical diseases and treatments. As we studied all persons equipped with a wireless BP monitor, and because its use has been endorsed by national guidelines and advocated by physicians, our population should mostly correspond to hypertensive patients. The observed greater reduction in patients with higher BP prior to the lockdown may confirm 
our hypothesis. Second, we cannot comment on the possible clinical relevance and the possible link to the observed AMI reduction - a 3/1.5 mmHg BP reduction in our population - although a similar BP reduction was associated with reduced stroke and AMI in the VALUE trial ${ }^{9}$.

\section{Conclusion}

The present study demonstrates a progressive decrease in SBP and DBP during the lockdown. Whether this could partly explain the concomitant reduction in the incidence of acute cardiovascular diseases remains to be studied.

\section{Authorship confirmation statement}

Nicolas Girerd: data analysis, writing and revision of the manuscript

Christophe Meune: data analysis, writing and revision of the manuscript

Kevin Duarte: statistics

Vincent Vercamer: data transfer

Marilucy Lopez-Sublet: writing and revision of the manuscript

Jean-Jacques Mourad: conception, data analysis, writing and revision of the manuscript

\section{Disclosure}

Vincent Vercamer is employed by Withings; however, he was neither involved in the data analysis nor in the decision to publish the results.

\section{Funding statement}

None to declare

\section{Figure legend}

Fig 1: Changes in systolic, diastolic blood pressure and heart rate prior to and during the COVID-19 lockdown in France 


\section{References}

1. Dong E, Du H, Gardner L. An interactive web-based dashboard to track COVID-19 in real time. The Lancet. Infectious diseases. May 2020;20(5):533-534.

2. De Filippo O, D'Ascenzo F, Angelini F, et al. Reduced Rate of Hospital Admissions for ACS during Covid-19 Outbreak in Northern Italy. N Engl J Med. Apr 282020.

3. Mesnier J, Cottin $Y$, Coste $P$, et al. Hospital admissions for acute myocardial infarction before and after lockdown according to regional prevalence of COVID-19 and patient profile in France: a registry study. The Lancet. Public health. Oct 2020;5(10):e536e542.

4. Fardman A, Oren D, Berkovitch A, et al. Post COVID-19 Acute Myocardial Infarction Rebound. The Canadian journal of cardiology. Nov 2020;36(11):1832 e1815-1832 e1816.

5. Rumsfeld JS, Joynt KE, Maddox TM. Big data analytics to improve cardiovascular care: promise and challenges. Nature reviews. Cardiology. Jun 2016;13(6):350-359.

6. Ghosh A, Arora B, Gupta R, Anoop S, Misra A. Effects of nationwide lockdown during COVID-19 epidemic on lifestyle and other medical issues of patients with type 2 diabetes in north India. Diabetes \& metabolic syndrome. Sep - Oct 2020;14(5):917920.

7. Kerneis M, Ferrante A, Guedeney P, Vicaut E, Montalescot G. Severe acute respiratory syndrome coronavirus 2 and renin-angiotensin system blockers: A review and pooled analysis. Arch Cardiovasc Dis. Dec 2020;113(12):797-810.

8. Munakata M. Clinical significance of stress-related increase in blood pressure: current evidence in office and out-of-office settings. Hypertens Res. Aug 2018;41(8):553-569.

9. Julius S, Kjeldsen SE, Weber M, et al. Outcomes in hypertensive patients at high cardiovascular risk treated with regimens based on valsartan or amlodipine: the VALUE randomised trial. Lancet. Jun 19 2004;363(9426):2022-2031.

Table 1: Changes in systolic and diastolic BP prior and during the country lock-down

\begin{tabular}{|c|c|c|c|c|c|c|}
\hline & \multicolumn{3}{|c|}{ Unadjusted random effect model } & \multicolumn{3}{|c|}{$\begin{array}{l}\text { Random effect model adjusted for age } \\
\text { and sex }\end{array}$} \\
\hline & \multirow{2}{*}{$\begin{array}{c}\text { Adjusted } \\
\text { Mean } \\
\pm \text { SE }\end{array}$} & \multicolumn{2}{|c|}{ Changes in BP } & \multirow{2}{*}{$\begin{array}{c}\text { Adjusted } \\
\text { Mean } \\
\pm \mathrm{SE} \\
\end{array}$} & \multicolumn{2}{|c|}{ Changes in BP } \\
\hline 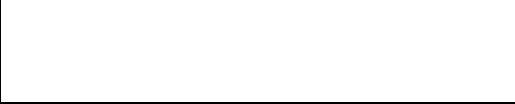 & & $\begin{array}{l}\text { Adjusted delta } \\
(95 \% \mathrm{CI})\end{array}$ & p-value & & $\begin{array}{l}\text { Adjusted delta } \\
(95 \% \mathrm{CI})\end{array}$ & p-value \\
\hline \multicolumn{7}{|l|}{ Systolic BP } \\
\hline January-March 2019 & $130.25 \pm 0.25$ & $\begin{array}{c}1.33(1.17 \text { to } \\
1.50)\end{array}$ & $<0.0001$ & $129.13 \pm 0.31$ & $\begin{array}{c}1.33(1.16 \text { to } \\
1.49)\end{array}$ & $<0.0001$ \\
\hline
\end{tabular}




\begin{tabular}{|c|c|c|c|c|c|c|}
\hline April-June 2019 & $129.27 \pm 0.25$ & $\begin{array}{c}0.35(0.19 \text { to } \\
0.51)\end{array}$ & 0.002 & $128.14 \pm 0.31$ & $\begin{array}{c}0.34(0.18 \text { to } \\
0.50)\end{array}$ & 0.002 \\
\hline July-September 2019 & $128.11 \pm 0.25$ & $\begin{array}{c}-0.81(-0.96 \text { to }- \\
0.66)\end{array}$ & $<0.0001$ & $126.99 \pm 0.31$ & $\begin{array}{c}-0.81(-0.96 \text { to }- \\
0.66)\end{array}$ & $<0.0001$ \\
\hline $\begin{array}{l}\text { October-December } \\
2019\end{array}$ & $129.73 \pm 0.24$ & $\begin{array}{l}0.81(0.69 \text { to } \\
0.94)\end{array}$ & $<0.0001$ & $128.61 \pm 0.31$ & $\begin{array}{c}0.81(0.68 \text { to } \\
0.94)\end{array}$ & $<0.0001$ \\
\hline $\begin{array}{l}2020 \text { prior to } \\
\text { lockdown (April } 5 \\
2020 \text { ) }\end{array}$ & $128.92 \pm 0.24$ & Reference & - & $127.80 \pm 0.30$ & 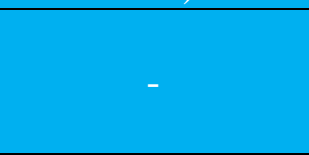 & - \\
\hline Lockdown week 1 & $127.91 \pm 0.27$ & $\begin{array}{c}-1.01(-1.26 \text { to }- \\
0.75)\end{array}$ & $<0.0001$ & $126.79 \pm 0.33$ & $\begin{array}{c}-1.01(-1.26 \text { to }- \\
0.76)\end{array}$ & $<0.0001$ \\
\hline Lockdown week 2 & $127.25 \pm 0.27$ & $\begin{array}{c}-1.67(-1.92 \text { to }- \\
1.41)\end{array}$ & $<0.0001$ & $126.14 \pm 0.33$ & $\begin{array}{c}-1.67(-1.92 \text { to }- \\
1.41)\end{array}$ & $<0.0001$ \\
\hline Lockdown week 3 & $127.12 \pm 0.27$ & $\begin{array}{c}-1.80(-2.06 \text { to }- \\
1.54)\end{array}$ & $<0.0001$ & $126.00 \pm 0.33$ & $\begin{array}{c}-1.80(-2.06 \text { to }- \\
1.54)\end{array}$ & $<0.0001$ \\
\hline Lockdown week 4 & $124.97 \pm 0.27$ & $\begin{array}{c}-3.94(-4.20 \text { to }- \\
3.69)\end{array}$ & $<0.0001$ & $123.86 \pm 0.33$ & $\begin{array}{c}-3.95(-4.20 \text { to }- \\
3.69)\end{array}$ & $<0.0001$ \\
\hline Lockdown week 5 & $125.81 \pm 0.27$ & $\begin{array}{c}-3.11(-3.37 \text { to }- \\
2.85)\end{array}$ & $<0.0001$ & $124.69 \pm 0.33$ & $\begin{array}{c}-3.11(-3.37 \text { to }- \\
2.85)\end{array}$ & $<0.0001$ \\
\hline Lockdown week 6 & $125.65 \pm 0.27$ & $\begin{array}{c}-3.27(-3.54 \text { to }- \\
3.01)\end{array}$ & $<0.0001$ & $124.53 \pm 0.33$ & $\begin{array}{c}-3.27(-3.54 \text { to }- \\
3.01)\end{array}$ & $<0.0001$ \\
\hline Lockdown week 7 & $126.52 \pm 0.27$ & $\begin{array}{c}-2.40(-2.67 \text { to }- \\
2.13) \\
\end{array}$ & $<0.0001$ & $125.40 \pm 0.33$ & $\begin{array}{c}-2.40(-2.67 \text { to }- \\
2.13) \\
\end{array}$ & $<0.0001$ \\
\hline \multicolumn{7}{|l|}{ Diastolic BP } \\
\hline January-March 2019 & $80.90 \pm 0.19$ & $\begin{array}{c}0.35(0.25 \text { to } \\
0.46) \\
\end{array}$ & $<0.0001$ & $79.57 \pm 0.23$ & $\begin{array}{c}0.35(0.25 \text { to } \\
0.46) \\
\end{array}$ & $<0.0001$ \\
\hline April-June 2019 & $80.46 \pm 0.19$ & $\begin{array}{c}-0.09(-0.19 \text { to } \\
0.02)\end{array}$ & 0.91 & $79.13 \pm 0.23$ & $\begin{array}{c}-0.09(-0.19 \text { to } \\
0.02)\end{array}$ & 0.91 \\
\hline July-September 2019 & $79.96 \pm 0.19$ & $\begin{array}{c}-0.58(-0.68 \text { to }- \\
0.49)\end{array}$ & $<0.0001$ & $78.63 \pm 0.23$ & $\begin{array}{c}-0.58(-0.68 \text { to }- \\
0.49)\end{array}$ & $<0.0001$ \\
\hline $\begin{array}{l}\text { October-December } \\
2019\end{array}$ & $81.04 \pm 0.18$ & $\begin{array}{l}0.50(0.41 \text { to } \\
0.58)\end{array}$ & $<0.0001$ & $79.71 \pm 0.23$ & $\begin{array}{l}0.50(0.41 \text { to } \\
0.58) \\
\end{array}$ & $<0.0001$ \\
\hline $\begin{array}{l}2020 \text { prior to } \\
\text { lockdown (April } 5 \\
\text { 2020) }\end{array}$ & $80.55 \pm 0.18$ & Reference & - & $79.21 \pm 0.23$ & - & - \\
\hline Lockdown week 1 & $79.96 \pm 0.20$ & $\begin{array}{c}-0.58(-0.75 \text { to }- \\
0.42)\end{array}$ & $<0.0001$ & $78.63 \pm 0.24$ & $\begin{array}{c}-0.58(-0.75 \text { to }- \\
0.42)\end{array}$ & $<0.0001$ \\
\hline Lockdown week 2 & $79.50 \pm 0.20$ & $\begin{array}{c}-1.05(-1.22 \text { to }- \\
0.88) \\
\end{array}$ & $<0.0001$ & $78.16 \pm 0.24$ & $\begin{array}{c}-1.05(-1.22 \text { to }- \\
0.88) \\
\end{array}$ & $<0.0001$ \\
\hline Lockdown week 3 & $79.52 \pm 0.20$ & $\begin{array}{c}-1.03(-1.20 \text { to }- \\
0.86)\end{array}$ & $<0.0001$ & $78.19 \pm 0.24$ & $\begin{array}{c}-1.03(-1.20 \text { to }- \\
0.86)\end{array}$ & $<0.0001$ \\
\hline Lockdown week 4 & $78.33 \pm 0.20$ & $\begin{array}{c}-2.22(-2.39 \text { to }- \\
2.05) \\
\end{array}$ & $<0.0001$ & $76.99 \pm 0.24$ & $\begin{array}{c}-2.22(-2.39 \text { to }- \\
2.05)\end{array}$ & $<0.0001$ \\
\hline Lockdown week 5 & $78.83 \pm 0.20$ & $\begin{array}{c}-1.72(-1.89 \text { to }- \\
1.55)\end{array}$ & $<0.0001$ & $77.50 \pm 0.24$ & $\begin{array}{c}-1.72(-1.89 \text { to }- \\
1.55)\end{array}$ & $<0.0001$ \\
\hline Lockdown week 6 & $78.82 \pm 0.20$ & $\begin{array}{c}-1.73(-1.90 \text { to }- \\
1.56)\end{array}$ & $<0.0001$ & $77.49 \pm 0.24$ & $\begin{array}{c}-1.73(-1.90 \text { to }- \\
1.56)\end{array}$ & $<0.0001$ \\
\hline Lockdown week 7 & $79.20 \pm 0.20$ & $\begin{array}{c}-1.35(-1.52 \text { to }- \\
1.17)\end{array}$ & $<0.0001$ & $77.87 \pm 0.24$ & $\begin{array}{c}-1.35(-1.52 \text { to }- \\
1.17)\end{array}$ & $<0.0001$ \\
\hline
\end{tabular}




\section{Figure 1:}
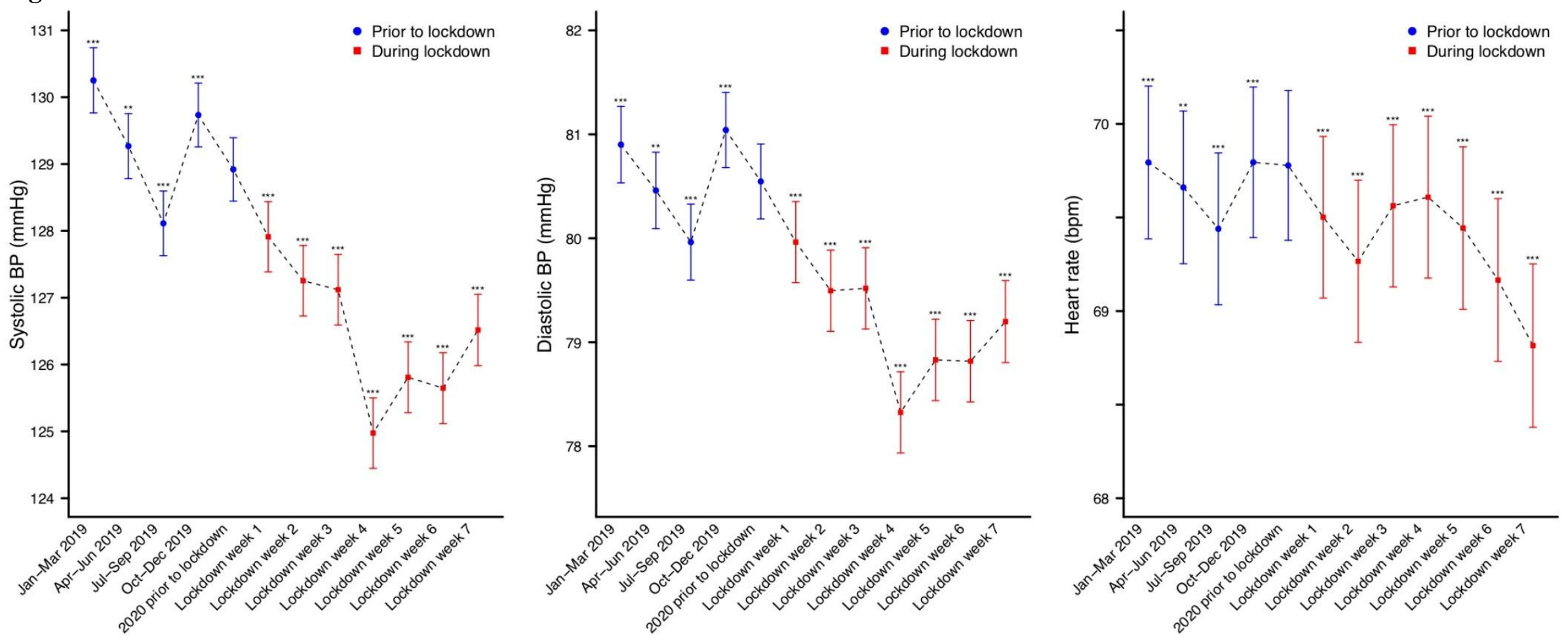